\title{
Erratum: Quebec Platelet Disorder: Update on Pathogenesis, Diagnosis, and Treatment
}

\author{
Catherine P.M. Hayward, MD, PhD, FRCP(C) ${ }^{1}$ Georges E. Rivard, MD, FRCP(C), FAAP ${ }^{2}$
}

${ }^{1}$ Department of Pathology and Molecular Medicine, McMaster University, Hamilton, Ontario, Canada

2 Service d'Hématologie-Oncologie, CHU Sainte-Justine, Montréal, Québec, Canada

\begin{abstract}
Address for correspondence Catherine P.M. Hayward, MD, PhD, FRCP (C), Department of Pathology and Molecular Medicine, McMaster University, 2N29A, 1200 Main St. W., Hamilton, Ontario, L8N 3Z5, Canada (e-mail: haywrdc@mcmaster.ca).
\end{abstract}

Semin Thromb Hemost 2019;45:121-122.

ERRATUM
The publisher has been informed that there were errors in - Table 1 in the above article in Seminars in Thrombosis and Hemostasis, Volume 37, Number 6, 2011 (DOI: 10.1055/s-00311291382).

The plasma thrombopoietin (TPO) values and TPO assay reference interval that the authors were provided were incorrect. They apologize for not catching these errors before publication. Plasma TPO levels (determined with new samples and the same assay) are actually $<31.3 \mathrm{pg} / \mathrm{ml}$ in QPD and most general population control samples. ${ }^{1}$ A new version of $\sim$ Table 1, with the correct information, ${ }^{1}$ is included in this erratum. No other information in the authors' review requires correction.
Issue Theme Editorial Compilation VI; Guest Editors: Emmanuel J. Favaloro, PhD, FFSc (RCPA), and Giuseppe Lippi, MD.
Copyright $\odot 2019$ by Thieme Medical Publishers, Inc., 333 Seventh Avenue, New York, NY 10001, USA. Tel: +1(212) 584-4662.
DOI https://doi.org/ 10.1055/s-0038-1625972. ISSN 0094-6176. 
Table 1 Laboratory findings in Quebec platelet disorder

\begin{tabular}{|c|c|}
\hline Laboratory test & Finding \\
\hline Platelet count & Reduced or normal $\left(80-245 \times 10^{9} / \mathrm{L}\right)$ \\
\hline Other blood counts & Normal unless iron deficient \\
\hline Platelet Function Analyzer-100® closure times & Normal \\
\hline Bleeding time & Normal to mildly prolonged \\
\hline \multicolumn{2}{|l|}{ Coagulation and fibrinolysis parameters } \\
\hline PT (INR) & Normal \\
\hline aPTT & Normal \\
\hline Fibrinogen & Normal \\
\hline D-dimer & Normal \\
\hline uPA & $\begin{array}{l}\text { Normal in plasma prepared with platelet activation inhibitors } \\
\left.\text { Elevated in platelets ( } \sim 400-600 \mathrm{ng} \text { uPA } / 10^{9} \text { platelets }\right)\end{array}$ \\
\hline uPA-plasminogen activator inhibitor 1 complexes & $\begin{array}{l}\text { Normal in plasma } \\
\text { Elevated in platelets }\end{array}$ \\
\hline Plasmin- $\alpha 2$ plasmin inhibitor complexes & $\begin{array}{l}\text { Normal in plasma } \\
\text { Elevated in platelets }\end{array}$ \\
\hline $\begin{array}{l}\text { Thromboelastography } \\
\text { (whole blood or platelet rich plasma) }\end{array}$ & Normal \\
\hline Light transmission platelet aggregometry & Non-diagnostic findings \\
\hline Epinephrine & Absent primary or absent secondary aggregation \\
\hline Adenosine diphosphate & Normal to reduced \\
\hline Collagen & Normal to reduced \\
\hline Arachidonic acid & Normal \\
\hline Thromboxane analogue U46619 & Normal \\
\hline Ristocetin & Normal \\
\hline \multicolumn{2}{|l|}{ Platelet glycoprotein analysis } \\
\hline $\begin{array}{l}\text { Western blot analysis for } \alpha \text {-granule } \\
\text { protein degradation and platelet uPA }\end{array}$ & $\alpha$-granule protein degradation and increased platelet uPA \\
\hline Plasma thrombopoietin levels & $<31.3 \mathrm{pg} / \mathrm{mL}$ (reference interval: $<31.3 \mathrm{pg} / \mathrm{mL}-196 \mathrm{pg} / \mathrm{mL}$ ) \\
\hline Genetic tests for the QPD PLAU duplication mutation & Positive (duplicated and normal alleles detected) \\
\hline
\end{tabular}

Abbreviations: ADP, adenosine diphosphate; aPTT, activated partial thromboplastin time; PT (INR), prothrombin time (international normalized ratio); QPD, Quebec platelet disorder; uPA, urokinase plasminogen activator.

Note: The only correction in this table, as compared with the previous version, relates to plasma thrombopoietin levels. All other information is as per previously published. The entire table is provided here for completeness and ease of referral.

\section{References}

1 Hayward CP, Tasneem S, Rivard GE. Thrombopoietin levels in Quebec platelet disorder: Implications for the mechanism of thrombocytopenia. Int J Lab Hematol 2018. Doi: 10.1111/ijlh.12781 